\section{Ecological and anthropogenic drivers of Calabrian pine (Pinus nigra J.F. Arn. ssp. laricio (Poiret) Maire) distribution in the Sila mountain range}

\author{
Antonino Nicolaci ${ }^{(1)}$, Davide Travaglini ${ }^{(2)}$, Giuliano Menguzzato ${ }^{(3)}$, \\ Susanna Nocentini ${ }^{(2)}$, Antonella Veltri ${ }^{(4)}$, Francesco lovino ${ }^{(1)}$
}

The most well-known and vast Calabrian pine forests are in the Sila mountain range, southern Italy. In this paper, present-day distribution of Calabrian pine in the Sila district was analyzed and compared with forest maps dating back to 1935 in order to assess the changes in land use. Main ecological and anthropogenic factors affecting Calabrian pine forest distribution were investigated by logistic regression models to identify the most important predictors of $\mathrm{Ca}$ labrian pine persistence, expansion, and transition over the period 1935-2006. In 2006, the area covered by Calabrian pine forests and mixed Calabrian pinebeech forests was 36100 ha and 20221 ha, respectively. Overall, pine forest area increased by $38 \%$ between 1935 and 2006. Logistic regression revealed that Calabrian pine distribution in the Sila district was affected by both ecological (bioclimate, soil, and elevation) and anthropogenic factors (management, fire). Based on our results, four different potential dynamics of Calabrian pine stands are discussed in the perspective of the sustainable management and conservation of this important mountain forest habitat.

Keywords: Ecological Factors, Forest Management, Land Use Changes, Forest Dynamics

\section{Introduction}

The Mediterranean basin is one of the major plant diversity hotspots and among the richest in endemism over the world (Médail \& Quézel 1999, Myers et al. 2000). In Europe, $80 \%$ of all endemic plants are Mediterranean species (Blondel \& Aronson 1995, Fady-Welterlen 2005), and Mediterranean forests are exceptionally rich in endemics: 201 of the 290 woody species and subspecies (shrubs and trees) in Europe are found exclusively or preferentially under Mediterranean bioclimates (Quézel \& Médail 2003).

Around the Mediterranean Basin, changes

in land-use and different forms of forest utilization over several millennia have shaped diverse landscape mosaics with different and often impacting consequences on biodiversity (Thirgood 1981, Blondel \& Aronson 1995, Blondel 2006). Forest distribution in Mediterranean landscapes is characterized by diverse environmental conditions in relation to climate, soils, and geology, as well as frequency and intensity of disturbance, both natural and anthropogenic. In the last decades, rapidly changing environmental conditions coupled with even more rapid changes in socio-economic conditions, es-

(1) Dipartimento di Ingegneria Informatica, Modellistica, Elettronica e Sistemistica, Università della Calabria, Arcavacata di Rende, Cosenza (Italy); (2) Dipartimento di Gestione di Sistemi Agrari, Alimentari e Forestali, Università degli Studi di Firenze, Firenze (Italy); (3) Dipartimento Gestione dei Sistemi Agrari e Forestali, Università degli Studi Mediterranea di Reggio Calabria, Reggio Calabria (Italy); (4) Istituto per i Sistemi Agricoli e Forestali del Mediterraneo, Consiglio Nazionale delle Ricerche, Rende, Cosenza (Italy)

@ Davide Travaglini (davide.travaglini@unifi.it)

Received: May 20, 2013 - Accepted: Jul 19, 2014

Citation: Nicolaci A, Travaglini D, Menguzzato G, Nocentini S, Veltri A, lovino F, 2014. Ecological and anthropogenic drivers of Calabrian pine (Pinus nigra J.F. Arn. ssp. laricio (Poiret) Maire) distribution in the Sila mountain range. iForest 8: 497-508 [online 2014-1110] URL: http://www.sisef.it/iforest/contents/?id=ifor1041-007

Communicated by: Renzo Motta pecially in rural and mountain areas, are posing new challenges for the conservation of forest habitats (Linares et al. 2009, DeSoto et al. 2010). Thus, an accurate knowledge base of ecological and anthropogenic drivers affecting the vegetation distribution is necessary for forest planning and for designing vegetation models (Tappeiner et al. 1998, Hoersch et al. 2002, Li et al. 2012). This knowledge is particularly important in highly sensitive areas such as in mountain territories, and especially within the Natura 2000 network, where habitat and species conservation is a mandatory goal.

Laricio pine (Pinus nigra J.F. Arn. ssp. laricio (Poiret) Maire), a sub-specific entity of the collective species Pinus nigra, includes 2 varieties: Corsican pine (var. Corsicana) and Calabrian pine (var. Calabrica - Debazac 1965). Corsican pine is the dominant species between 1000 and $1800 \mathrm{~m}$ a.s.l. on the mountains of Corsica, where it covers approximately 45000 ha, of which 21000 ha are pure Corsican pine stands (LIFE 2005).

Calabrian pine is endemic to southern Italy with a natural range extending from Calabria to Sicily. Calabrian pine forests (Cod. Eunis, G3.55, Calabrian Pinus laricio forest; Cod. CORINE Biotopes, 42.65, Calabrian laricio pine forests) are a priority habitat according to the Natura 2000 Directive (Cod. 9530* (Sub)-Mediterranean pine forests with endemic black pines - EC 2007, Zaghi 2008).

During the last ice age (the Würm period in the Alps) Calabrian pine covered vast areas of the Apennines. In the Boreal period, $\mathrm{Ca}$ labrian pine expansion slowed down due to competition with silver fir (Abies alba Mill.) and beech (Fagus sylvatica L.) at higher altitudes, and with oaks at lower altitudes (Barbéro et al. 2000), restricting pine distribution to the less favorable site conditions (Tongiorgi 1938). At the end of this period, Calabrian pine started to expand again into areas where human activities (primarily forest clearing and fire) destroyed the forest cover and caused extensive soil degradation. A pedostratigraphic study by Dimase et al. (1996) showed that periods of reduced soil erosion alternated with periods of intense erosion that coincided with intensive agriculture and grazing, which occurred in the $12^{\text {th }}$ to $13^{\text {th }}$ centuries, then again in the $15^{\text {th }}$ to $16^{\text {th }}$ centuries, and finally after the $18^{\text {th }}$ century (Fig. 1).

Today, Calabrian pine grows in Sicily in fragmented areas on the slopes of Mount Etna between 1000 and $2000 \mathrm{~m}$ a.s.l., covering approximately 3000 ha (Poli Marchese 1982, Barreca et al. 2009). In Calabria it grows on the Sila and Aspromonte mountains, covering approximately 114000 ha, of which more than $50 \%$ are pure stands of both natural and artificial origin. The latter originated from extensive reforestation projects 


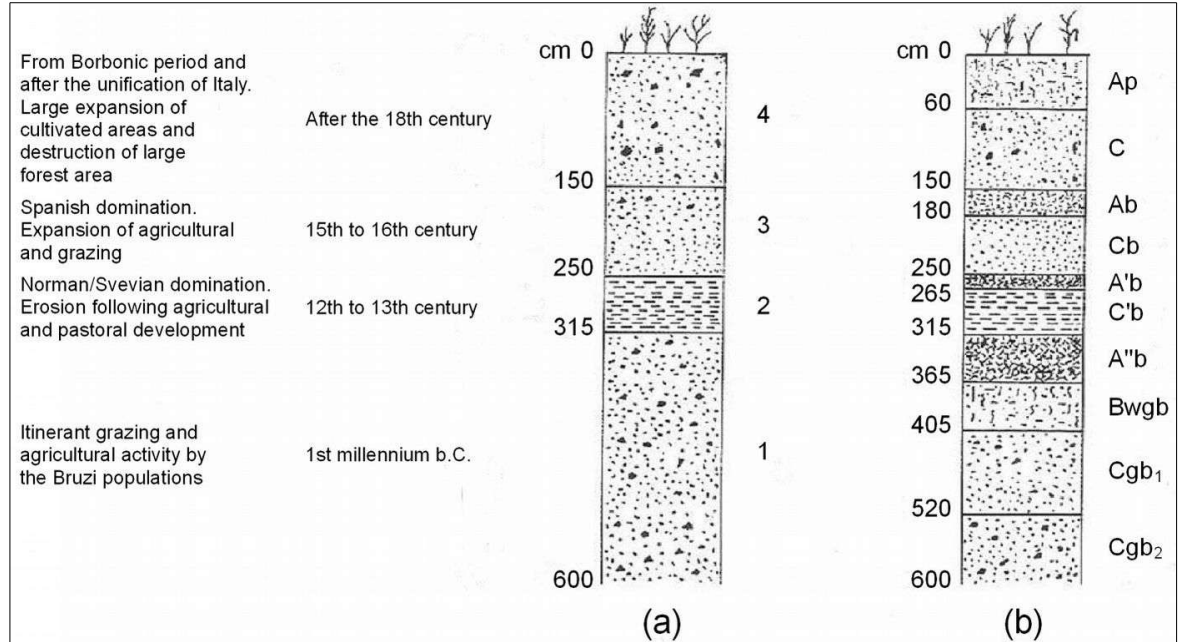

Fig. 1 - Outline of a pedostratigraphic section near Lake Cecita of the Sila Plateau (modified from Dimase et al. 1996). (a) Sediments of the main sedimentation phases $(1,2,3,4)$. (b) Soils developed during the period between the end of each phase of sedimentation and the beginning of the following phase.

carried out between 1950 and 1970 following specific State laws (Iovino \& Menguzzato 2002a, 2002b).

The largest area covered by Calabrian pine is in the Sila mountain range, where this species characterizes the forest landscape. Together with soil conservation and watershed protection, Calabrian pine has an important role in the local forest economy. In public properties (townships and State forests), management of Calabrian pine has usually been based on various types of clear felling (strip or patch), whereas on private propernaged according to traditional and locally developed forms of selection cutting, which have contributed to the maintenance of pure pine stands with complex structures (Ciancio et al. 2006). More recently, in State forests within the Sila National Park, management has been limited to felling only dead or dying trees. In these forests, and in other areas where for various reasons active management of Calabrian pine stands has stopped, broadleaved trees are spreading under the older pine trees (Iovino \& Men- ties, pine stands have generally been ma-
Fig. 2 - The study area.

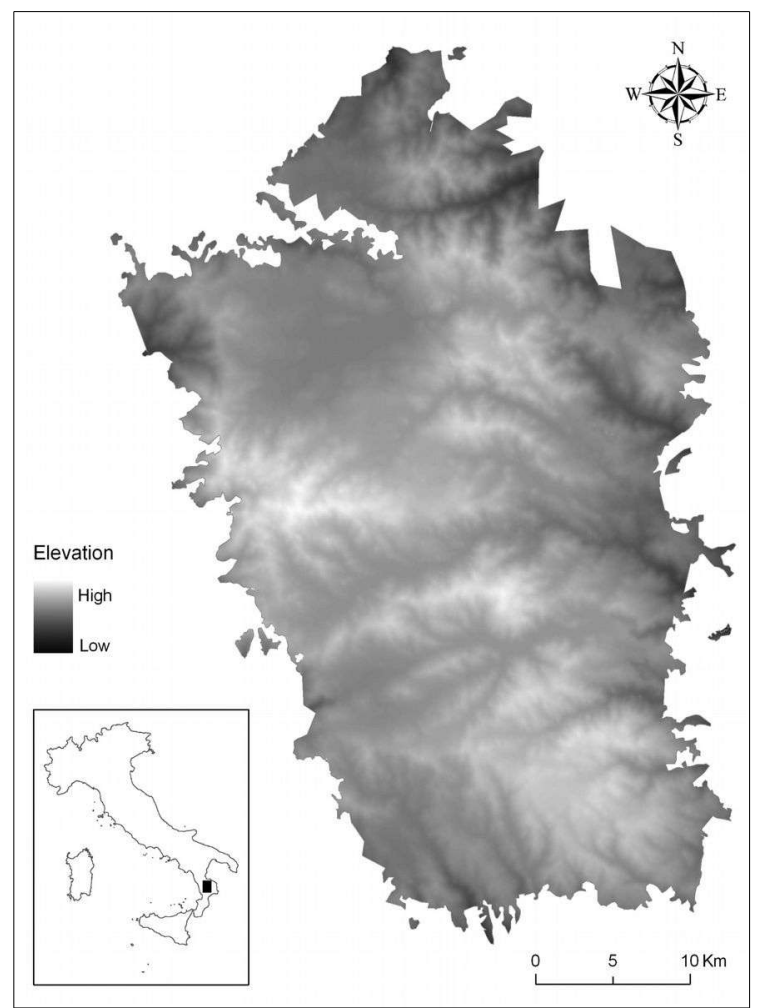

guzzato 1996). Thus, the primary environmental factors determining the occurrence and competitiveness of Calabrian pine are strongly influenced by anthropogenic activity.

In order to understand the ecological and anthropogenic factors driving Calabrian pine distribution in the Sila mountain range, we address 4 objectives: (1) to analyze presentday Calabrian pine distribution; (2) to determine forest cover changes in the period 1935-2006; (3) to characterize climate and soil conditions where Calabrian pine grows; and (4) to identify the most significant variables that have led to species' persistence, expansion or transition in the last 70 years. We outline the potential dynamics of Calabrian pine forests for the near future in relation to changes in ecological and anthropogenic drivers. Our aim is to provide a tool for the decision-making process in forest planning, specifically where conservation of pine habitat is the main management objective.

\section{Material and methods}

\section{Study area}

The Sila mountain range $\left(16^{\circ} 20^{\prime} 9.5^{\prime \prime}-16^{\circ}\right.$ $\left.45^{\prime} 44.4^{\prime \prime} \mathrm{E}, 39^{\circ} 00^{\prime} 30.9^{\prime \prime}-39^{\circ} 33^{\prime} 45.4^{\prime \prime} \mathrm{N}\right)$ covers an area of approximately $1302 \mathrm{~km}^{2}$ (Fig. 2), and is conventionally divided into 3 geographic zones named, from north to south, Sila Greca, Sila Grande, and Sila Piccola, respectively. The Sila Greca lies in the northern part of the mountain range, and is characterized by very steep slopes and altitudes ranging between 900 and $1650 \mathrm{~m}$ a.s.l. In the past, Calabrian pine was planted mostly at elevations higher than $900 \mathrm{~m}$ a.s.l. The Sila Grande is a vast area extending from 1100 up to 1928 m a.s.l. on Mount Botte Donato. The Sila Piccola is located in the southern part of the mountain range at altitudes between 1200 and $1765 \mathrm{~m}$ a.s.l. and incorporates Mount Gariglione. The Sila mountain range is characterized by wide, almost flat or slightly sloping areas, modeled in a Paleozoic substratum of igneous-metamorphic rock or in a Miocenic deposit during the Pliocene (Dramis et al. 1990, Sorriso-Valvo 1993, Matano \& Di Nocera 1999, Molin et al. 2004).

\section{Dataset}

Present-day forest cover was obtained from Corine Land Cover 2000 map (CLC 2000). We used the fourth thematic level for maps of Italy at a nominal scale of 1:100,000, which consist of 23 forest classes (Bonora et al. 2011). A forest map produced by the $\mathrm{Na}$ tional Forest Service in 1935 at a scale of 1:100,000 (Milizia Nazionale Forestale 1932) was used for land cover change analysis.

To identify the main drivers of change in land cover, we analyzed elevation, aspect, 
slope, climate, and soil type. Elevation data were extracted from a digital terrain model (DTM) available for Italy with a pixel size of $250 \mathrm{~m}$ (Blasi et al. 2007). Aspect and slope were computed from the DTM. The climate was analyzed using monthly temperature and precipitation maps with a $250 \mathrm{~m}$ pixel size. Monthly data were elaborated at the national scale by using locally calibrated regressions from a database of 403 weather stations distributed across Italy with a 30 -year time series (Blasi et al. 2007). A bioclimate map for the study area was generated from monthly data (Rivas Martinez 1995). We used the historical dataset (1921-2010) of monthly and yearly precipitations from 19 weather stations distributed across the study area to provide additional information on climate conditions (MLP 1950). Because temperature was only recorded on 5 of these weather stations, it was estimated for the remaining stations by a local regression equation between elevation and temperature (Ciancio 1971). For each station, we derived climatic diagrams and the following bioclimatic indexes: thermicity index, continentality index, ombrothermic index, and compensated index (Rivas Martinez 1995).

Soil types according to the USDA soil classification system (Soil Survey Staff 1999) were extracted from a soil map $(1: 250,000)$ produced by the Calabrian Regional Agency for Development and Services in Agriculture (ARSSA 2003). Ancillary soil information from local studies was also used to interpret soil data (Dimase \& Iovino 1996, Lulli \& Vecchio 1996, 2000, Scarciglia et al. 2005).

\section{Forest distribution and analysis of land- cover change}

Shape and classification of forest polygons extracted from the CLC 2000 map were verified by visual interpretation of digital orthophotos acquired in 2006. We discriminated between pure and mixed forests using $75 \%$ of total crown cover as the threshold and the minimum Corine Land Cover (CLC) map- ping unit. After this procedure, no forest changes were detected in the study area between 2000 and 2006. We then reclassified the CLC into 9 forest classes: Calabrian pine forest (both plantations and natural stands); mixed Calabrian pine-beech forest (pure natural pine stands alternating with beech on small areas); beech forest with sparse Calabrian pine (beech forest with different sized and shaped pine groups); beech forest; mixed fir-beech forest; chestnut forest; other coniferous forest; other broadleaved forest; and non-forest. In this way, we produced a forest map for the Sila mountain range updated to 2006 .

The present-day distribution of forest classes was compared with the forest distribution reported in 1935 by the National Forest Service. A cross-tabulation analysis was used to detect land cover changes (Chirici et al. 2006). We applied a map generalization procedure to reduce the geometric and thematic discrepancies between the historical and the present-day forest maps (Petit \& Lambin 2001, Pelorosso et al. 2009). First, a thematic generalization was applied to each forest map by merging the initial forest classes into 7 classes: Calabrian pine forest; mixed fir-beech forest; beech forest; chestnut forest; other coniferous forest; other broadleaved forest; and non-forest. Then we performed successive spatial aggregations from $50 \mathrm{~m}$ up to $400 \mathrm{~m}$ using a majorityrule aggregation procedure to identify the best pixel size for change analysis following the method of Petit \& Lambin (2001). After this procedure, a pixel size of $250 \mathrm{~m}$ was used for cross-tabulation analysis.

\section{Relationship between forest classes and ecological factors}

\section{Preliminary analysis}

Geographical information system tools (overlay and summary) were used to produce graphs and scatter-plots for a visual interpretation of the ranges of ecological variables. Analyses were carried out for every ecological factor with all forest classes. Graphs were created to interpret the relationships between single ecological variables and forest classes. Scatter-plots were used to analyze the bi-dimensional relationships between elevation and aspect.

\section{Factors driving Calabrian pine distribution}

To identify the explanatory variables affecting Calabrian pine distribution we used a binary logistic regression analysis. This type of statistical model is used to describe the relationship between a binary (presence-absence or 1-0) dependent variable (i.e., land cover change vs. no land cover change), and a set of continuous or categorical independent, or explanatory, variables (Kleinbaum \& Klein 2002). For instance, Poljanec et al. (2010) used a logistic regression model to analyze changes in the distribution of European beech in Slovenia between 1975 and 2005 in terms of selected site, stand, and management variables. Mon et al. (2012) used a logistic regression to examine the factors influencing deforestation and forest degradation in production forests of the central Bago Mountain area in Myanmar. Monzón-Alvarado et al. (2012) employed logistic regression analysis to assess the likelihood of deforestation following forest fires in Laguna del Tigre National Park, Guatemala. Getahun et al. (2013), Newman et al. (2014), Schweizer \& Matlack (2014) used logistic regressions to study socio-economic factors and environmental variables driving land cover changes. In addition, several authors (Badia et al. 2011, Arndt et al. 2013, Botequim et al. 2013) used logistic regressions to identify the most important biophysical and human variables explaining the spatial occurrence of fire ignitions.

In our case, 3 logistic regressions were performed after analysis of land-use change to identify the most important explanatory variables for Calabrian pine persistence, expan-

Tab. 1 - Dependent and independent variables used in the binary logistic regression. $\left(^{*}\right)$ : HD HPD = Humic Dystrudept, and Humic Psammentic Dystrudept; HD_TD = Humic Dystrudept and Typic Dystrudept; TD_HD = Typic Dystrudept and Humic Dystrudept; HPD_HD_TD = Humic Psammentic Dystrudept, Humic Dystrudept and Typic Dystrudept; HLD HD RO = Humic Lithic Dystrudept, Humic Dystrudept and Rock outcrop; HPD_HD_RO = Humic Psammentic Dystrudept, Humic Dystrudept and Rock outcrop.

\begin{tabular}{|c|c|c|c|c|}
\hline Role & Variables & Source & Variable type & Notes \\
\hline \multirow[t]{3}{*}{ Dependent } & Calabrian pine persistence & Analysis of land-use change (this study) & Binary & $1=$ yes; $0=$ no \\
\hline & Calabrian pine expansion & Analysis of land-use change (this study) & Binary & $1=$ yes; $0=$ no \\
\hline & Calabrian pine transition & Analysis of land-use change (this study) & Binary & $1=$ yes $; 0=$ no \\
\hline \multirow[t]{5}{*}{$\begin{array}{l}\text { Indepen- } \\
\text { dent }\end{array}$} & Bioclimate & $\begin{array}{l}\text { Own elaboration from monthly temperature } \\
\text { and precipitation maps (Blasi et al. 2007) }\end{array}$ & Binary & $\begin{array}{c}1=\text { oceanic Mediterranean; } \\
2=\text { temperate oceanic }\end{array}$ \\
\hline & Elevation & DTM (Blasi et al. 2007) & Ordinal & Reclassified into $100 \mathrm{~m}$ intervals \\
\hline & Aspect & Own elaboration from DTM & Categorical & $\begin{array}{c}1=\mathrm{N} ; 2=\mathrm{NE} ; 3=\mathrm{E} ; 4=\mathrm{SE} ; 5=\mathrm{S} \\
6=\mathrm{SW} ; 7=\mathrm{W} ; 8=\mathrm{NW} ; 9=\text { flat }\end{array}$ \\
\hline & Slope & Own elaboration from DTM & Ordinal & Reclassified into $20 \%$ intervals \\
\hline & Soil type* & Soil map (ARSSA 2003) & Categorical & $\begin{array}{c}1=\text { HD_HPD; } 2=\text { HD_TD; } \\
3=\text { TD_HD; } 4=\text { HPD_HD_TD; } \\
5=\text { HLD_HD_RO; } 6=\text { HPD_HD_RO }\end{array}$ \\
\hline
\end{tabular}




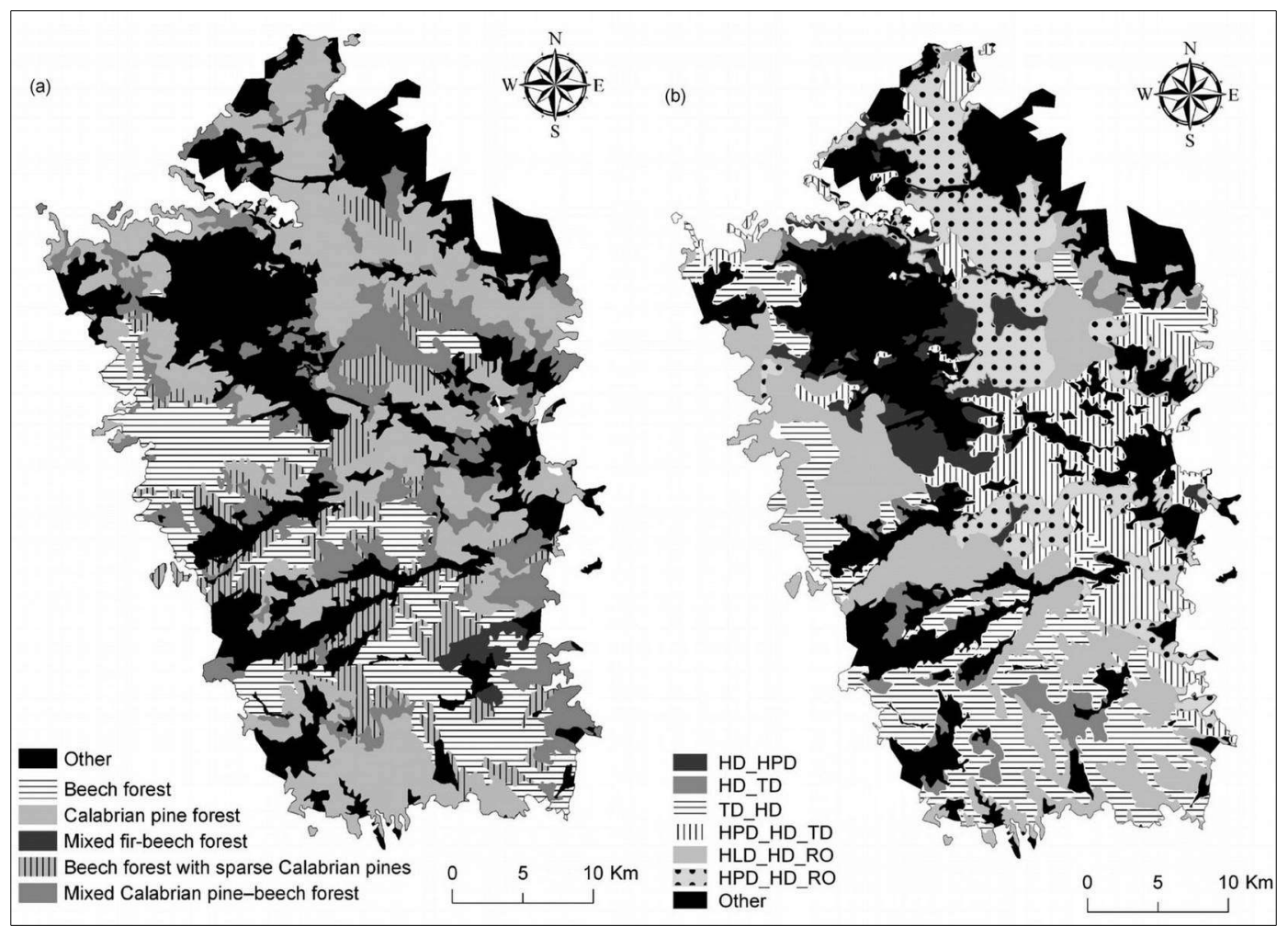

Fig. 3 - (a) Distribution of forest classes (2006) in the Sila mountain range. (b) Distribution of soil types (ARSSA 2003) classified according to the USDA soil classification system (see Tab. 1 for soil type description).

sion, and transition during 1935-2006 (Tab. $1)$.

The vector data format was transformed into a raster data format using a pixel size of $250 \mathrm{~m}$. Then we established a systematic, 1$\mathrm{km}$ sampling network over the study area, and obtained a 916-pixel sample, which reduced the effect of spatial autocorrelation in the spatial distribution of observation points (Linkie et al. 2004, Mon et al. 2012, Schweizer \& Matlack 2014). Only the pixels that were candidates for the type of event (persistence, expansion, or transition) were selected for the regression analysis. Specifically, in the pine-persistence model only pixels that were Calabrian pine stands in 1935 and 2006 were selected; in the pine-expansion model only pixels that were non-pine stands in 1935 and pine stands in 2006 were considered; and in the pine-transition model only pixels that were pine stands in 1935 and non-pine stands in 2006 were used. Thus, there were $\mathrm{n}=182$, $\mathrm{n}=154$, and $\mathrm{n}=128$ candidate pixels for the persistence model, the expansion model, and the transition model, respectively. A binary dependent variable was created for each model, with value 1 for candidate pixels representing the type of change under examination, and 0 for an equal number of randomly selected non-candidate pixels. The attributes of the independent variables for each candidate and non-candidate pixels were extracted by spatial analysis tools and exported to
SPSS ${ }^{\circledR}$ v. 20 for statistical analysis.

High collinearity between the independent variables was verified by the variance inflation factor (VIF), and the tolerance was verified using linear regression (Mon et al. 2012). High collinearity occurs when tolerance is less than 0.2 , or VIF is greater than 4 (Eeckhaut et al. 2006). High collinearity was not detected in our study.

The independent variables were included in a logistic regression using the forward stepwise algorithm (entry 0.50, removal 0.10 ), based on the maximum likelihood criterion used to reduce the number of independent variables to the most explicative (Badia et al. 2011, Monzón-Alvarado et al. 2012, Arndt et al. 2013). We examined Wald's statistics to identify the relative importance of the contributions of explanatory variables (Mon et al. 2012, Arndt et al. 2013). The odds ratios of significant parameters $(p<0.05)$ were used to facilitate model interpretation (Mertens \& Lambin 2000, Serneels \& Lambin 2001). Odds ratios $>1($ or $<1)$ indicate an increased (or a decreased) likelihood of occurrence of the event (Mon et al. 2012, Arndt et al. 2013). The goodness-of-fit was tested using the Hosmer-Lemeshow test (Poljanec et al. 2010, Botequim et al. 2013). If the goodness-of-fit test statistic was $>0.05$, we considered that there was no difference between the observed and the predicted val- ues, indicating that the model's estimates fit the data to an acceptable level (Hair et al. 2006).

\section{Results}

\section{Forest distribution}

The distribution of forest classes in the Sila mountain range are presented in Fig. 3a. At present, Calabrian pine forests (both plantations and natural stands) were found to cover $28 \%$ of the studied area, while $10 \%$ was covered by beech forests with sparse Calabrian pine (Tab. 2). Most Calabrian pine forests grew in the Sila Grande (37\% of forest area); the remaining pine forests were almost equally distributed between the Sila Greca (55\% of forest area) and the Sila Piccola (27\% - Fig. 4).

Pine plantations and natural pine forests were not distinguished from each other in our study. Nevertheless, field observations and literature data show that natural pine forests grow between $800-1000 \mathrm{~m}$ a.s.l., and 1500$1600 \mathrm{~m}$ a.s.l., while plantations were located between 900 and 1200-1300 m a.s.l., as a consequence of the reforestation activities carried out from 1950 to 1970 (Iovino \& Menguzzato 2002a).

Mixed Calabrian pine-beech forests and beech forests with sparse Calabrian pine were spatially adjacent to pure pine forests. These 2 forest classes reflect different beech forest 
dynamic stages: the former occurred where beech was partially replaced by pine due to intensive cuts in the past; the latter intermingled with pure beech forests especially in the southern, western, and central areas of the Sila mountain range. In the Sila Greca and the Sila Grande, beech forests with sparse Calabrian pine covered $6 \%$ and $13 \%$ of forest area, respectively; the area covered by this forest class in the Sila mountain range was equal to $13 \%$ of the total forest area (Tab. 2).

Pure beech forests prevailed in the southern area and in the western and central areas from $1400-1500 \mathrm{~m}$ a.s.l. up to the mountain top (Fig. 4). In the Sila Grande and the Sila Piccola, beech forests covered $20 \%$ and $33 \%$ of the forest area, respectively; the area covered by beech in the Sila mountain range was equal to $21 \%$ of the total forest area (Tab. 2).

The most important area for spontaneous fir vegetation was in the Sila Piccola (Tab. 2), where mixed fir-beech forests spread over 1100 ha $(4 \%$ of forest area in the Sila Piccola), at elevation ranging from 1200 and $1600 \mathrm{~m}$ a.s.l. (Fig. 4).

\section{Land cover changes}

At present, the area covered by Calabrian pine forests and mixed Calabrian pine-beech forests is equal to 36100 ha and 20221 ha, respectively (Tab. 2). In 1935, the total area covered by pine was 40888 ha. Overall, pine forest area has increased 38\% between 1935 and 2006. The cross-tabulation analysis (Tab. 3 ) shows that most of these new pine forests (approx. 65\%) occurred in the previously non-forested class because of reforestation projects after World War II (Iovino \& Menguzzato 2002b). However, pine forests have also replaced other forest classes (approx. $35 \%$ ), especially beech, chestnut, and other broadleaved forests. It is also worth noting that $46 \%$ of the current pine forest area was present in 1935, indicating the persistence of this forest class in the Sila mountain range (Fig. 5). Additionally, cross-tabulation analysis showed that during 1935 to 2006, parts of pine forests changed to other classes: about $46 \%$ changed into beech forest, $6 \%$ into other forest classes, and $46 \%$ were transformed into other land uses.

\section{Climate}

Calabrian pine forests grew in an oceanic Mediterranean bioclimate from the lower limit (800 to $900 \mathrm{~m}$ a.s.1.) up to $1200 \mathrm{~m}$ a.s.l., and in a temperate oceanic bioclimate at higher elevations. Thermotype and ombrotype for 19 weather stations in the Sila mountain range are reported in Tab. 4.

The average yearly precipitation exceeded $1000 \mathrm{~mm}$ with an increasing trend from the northern and eastern areas to the southern area of the Sila mountain range. The maximum precipitation was $1631 \mathrm{~mm}$. The mean
Tab. 2 - Forest classes in the Sila mountain range.

\begin{tabular}{|c|c|c|c|c|c|c|c|c|}
\hline \multirow{2}{*}{ Forest class } & \multicolumn{2}{|c|}{ Sila Greca } & \multicolumn{2}{|c|}{ Sila Grande } & \multicolumn{2}{|c|}{ Sila Piccola } & \multicolumn{2}{|c|}{ Total } \\
\hline & ha & $\%$ & ha & $\%$ & ha & $\%$ & ha & $\%$ \\
\hline Calabrian pine forest & 7348 & 39 & 20722 & 26 & 8030 & 25 & 36100 & 28 \\
\hline $\begin{array}{l}\text { Mixed Calabrian pine-beech } \\
\text { forest }\end{array}$ & 1495 & 8 & 14059 & 18 & 4668 & 15 & 20221 & 16 \\
\hline $\begin{array}{l}\text { Beech forest with sparse } \\
\text { Calabrian pine }\end{array}$ & 791 & 4 & 7257 & 9 & 5125 & 16 & 13173 & 10 \\
\hline Beech forest & 0 & 0 & 10908 & 14 & 9883 & 31 & 20791 & 16 \\
\hline Mixed fir-beech forest & 0 & 0 & 0 & 0 & 1187 & 4 & 1187 & 1 \\
\hline Chestnut forest & 258 & 1 & 1621 & 2 & 394 & 1 & 2273 & 2 \\
\hline Other coniferous forest & 86 & 0 & 511 & 1 & 0 & 0 & 597 & 0 \\
\hline Other broadleaved forest & 3357 & 18 & 788 & 1 & 217 & 1 & 4362 & 3 \\
\hline Non-forest & 5583 & 30 & 23190 & 29 & 2689 & 8 & 31462 & 24 \\
\hline Total & 18918 & 100 & 79056 & 100 & 32193 & 100 & 130166 & 100 \\
\hline
\end{tabular}

Tab. 3 - Forest cover changes of most important forest classes (in hectares) between 1935 (columns) and 2006 (rows).

\begin{tabular}{|c|c|c|c|c|c|c|c|c|}
\hline \multirow[b]{2}{*}{2006} & \multicolumn{8}{|c|}{1935} \\
\hline & 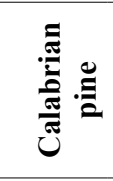 & 离 & ల్ల & 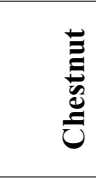 & 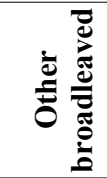 & 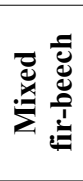 & $\frac{\overrightarrow{0}}{\stackrel{\Delta}{0}}$ & हึँ \\
\hline Calabrian pine & 26006 & 0 & 4181 & 844 & 5738 & 0 & 19756 & 56525 \\
\hline Other coniferous & 19 & 0 & 0 & 0 & 56 & 0 & 525 & 600 \\
\hline Beech & 6756 & 0 & 158383 & 944 & 2638 & 0 & 7806 & 33981 \\
\hline Chestnut & 200 & 0 & 263 & 144 & 475 & 0 & 1213 & 2294 \\
\hline Other broadleaved & 725 & 0 & 0 & 94 & 2531 & 0 & 963 & 4313 \\
\hline Mixed fir-beech & 0 & 0 & 988 & 0 & 181 & 0 & 6 & 1.175 \\
\hline Non-forest & 7181 & 0 & 1600 & 306 & 3469 & 0 & 18722 & 31278 \\
\hline Total & 40888 & 0 & 228694 & 2331 & 15088 & 0 & 48991 & 130166 \\
\hline
\end{tabular}

\begin{tabular}{|c|c|c|c|c|c|c|}
\hline 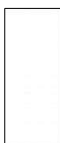 & $\begin{array}{l}\text { Calabrian pine } \\
\text { forest }\end{array}$ & $\begin{array}{c}\text { Mixed } \\
\text { Calabrian } \\
\text { pine-beech } \\
\text { forest }\end{array}$ & $\begin{array}{l}\text { Beech forest } \\
\text { with sparse } \\
\text { Calabrian pine }\end{array}$ & Beech forest & $\begin{array}{c}\text { Mixed fir- } \\
\text { beech forest }\end{array}$ & Legend \\
\hline อั & & & & & & $\begin{array}{l}\text { - Sila Greca } \\
\text { W Sila Grande } \\
\text { "Sila Piccola }\end{array}$ \\
\hline 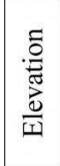 & & & & & & 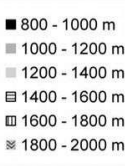 \\
\hline 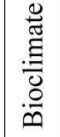 & & & & & & $\begin{array}{l}\text { - Oceanic } \\
\text { Mediterranean } \\
\text { = Temperate } \\
\text { oceanic }\end{array}$ \\
\hline$\overline{0}$ & & & & & & 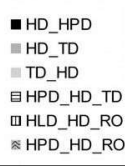 \\
\hline
\end{tabular}

Fig. 4 - Distribution of the most important forest classes (for each class, the area is a percentage of total forest class area) into geographical zones, elevation, bioclimate, and soil (see Tab. 1 for soil type description). 
Fig. 5 - Changes in Calabrian pine cover between 1935 and 2006 .

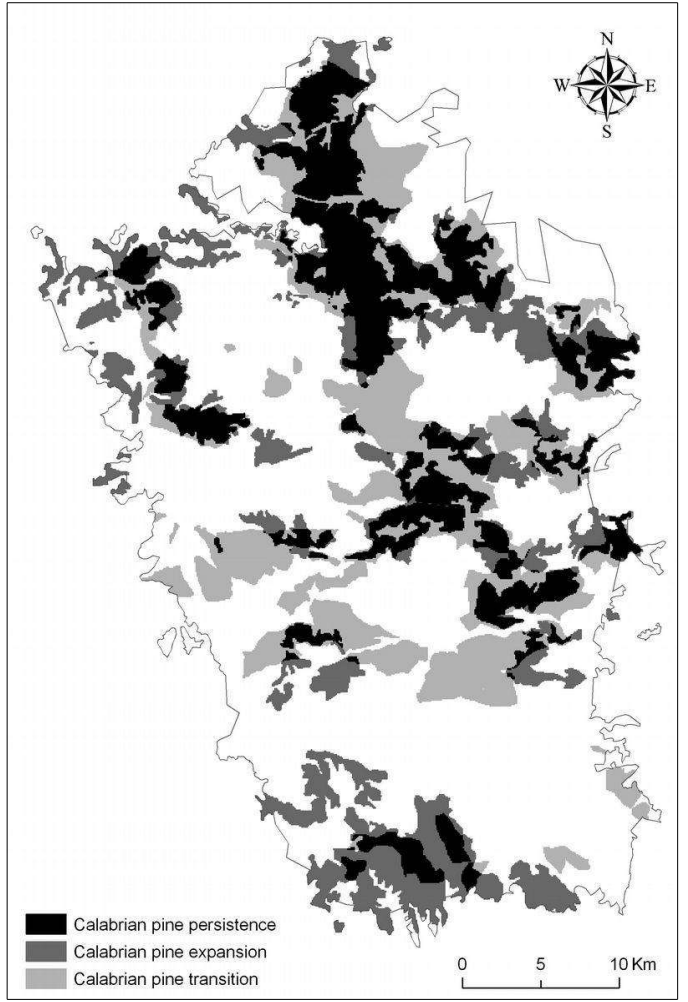

The mean temperature ranged between 12.8 and $8.6{ }^{\circ} \mathrm{C}$. The mean temperature at the lower (900 m a.s.1.) and higher limits (1650 $\mathrm{m}$ a.s.l.) of pine growth were 11.9 and $6.5^{\circ} \mathrm{C}$, respectively. The mean monthly temperature between January and March varied between -2.6 and $0{ }^{\circ} \mathrm{C}$, while the mean monthly temperature in July and August ranged from 16 to $18{ }^{\circ} \mathrm{C}$. Between November and April, the daily temperature reached a minimum value of $-10^{\circ} \mathrm{C}$, while in summer reached a maximum of 30 to $32^{\circ} \mathrm{C}$.

\section{Soil}

Pine forests grew on different soils (Fig. $3 b)$ depending on parent material, slope, and human impact. In the northern and eastern zones, pine forests were found on steep slopes on soils from altered granitic rocks of the following soil types (USDA soil classification system): Humic Psammentic Dystrudept, Humic Dystrudept and Rock outcrop (HPD_HD_RO). The HPD were thin soils with an A-Cr profile, a scarce skeleton with a coarse texture, acidic, a low water reserve, and fast drainage. The HD RO were moderately deep soils with an Oi-A-Bw-Cr profile, a skeleton varying from scarce to common with moderately coarse texture, acidic, a high water reserve, and good drainage (ARSSA 2003). These soil types were also present in some areas of the northern and eastern zones.

In the central zone, Calabrian pine was found on soils originated on moderate slopes from altered granitic rocks of the following soil type: Humic Psammentic Dystrudept, Humic Dystrudept, and Typic Dystrudept (HPD_HD_TD). The 2 most common profiles were: (i) Oi-A-Bw-Cr, moderately deep with a skeleton varying from scarce to common; and (ii) Oi-A-Bw-BC-Cr, moderately for 6 months at elevations $>1400$ to $1600 \mathrm{~m}$ a.s.1., especially in cool aspects (MLP 1950).

Tab. 4 - Thermotype and ombrotype for 19 weather stations distributed across the study area. (E): Elevation; (P): average yearly precipita tion; (T): average yearly temperature; (It): $10(\mathrm{~T}+\mathrm{M}+\mathrm{m})$, where $\mathrm{M}=$ mean of maximum temperature of the cold months, and $\mathrm{m}=\mathrm{mean}$ of minimum temperature of the cold months; (Ic): Tmax - Tmin, where Tmax $=$ mean temperature of the warm months, and Tmin $=$ mean temperature of the cold months. (Iov3): Ppsv3 / Tpsv3, where Ppsv3 = mean precipitation in June, July and August, and Tpsv3 = mean tempera ture in June, July and August; (Iov4): Ppsv4 / Tpsv4, where Ppsv4 = mean precipitation in May, June, July and August, and Tpsv4 = mean temperature in May, June, July and August). $\left({ }^{*}\right): 1$ = oceanic Mediterranean, 2 = Temperate oceanic; $(* *): 1=$ Meso-Mediterranean higher, 2 = Supra-Mediterranean medium, $3=$ Supra-Mediterranean higher, $4=$ Mountain higher, $5=$ Supra-Mediterranean lower, $6=$ Mountain lower. $(* * *)$ : 1 = Humid higher, 2 = Humid lower, 3 = Iper-humid lower.

\begin{tabular}{|c|c|c|c|c|c|c|c|c|c|c|}
\hline \multirow{2}{*}{$\begin{array}{l}\text { Weather } \\
\text { station }\end{array}$} & \multirow{2}{*}{$\begin{array}{c}E \\
\text { (m a.s.l.) }\end{array}$} & \multirow{2}{*}{$\begin{array}{c}\mathbf{P} \\
(\mathbf{m m})\end{array}$} & \multirow{2}{*}{$\begin{array}{c}\mathbf{T} \\
\left({ }^{\circ} \mathbf{C}\right)\end{array}$} & \multicolumn{4}{|c|}{ Rivas Martinez } & \multirow{2}{*}{$\begin{array}{l}\text { Biocli- } \\
\text { mate* }\end{array}$} & \multirow{2}{*}{$\begin{array}{c}\text { Thermo- } \\
\text { type*** }\end{array}$} & \multirow{2}{*}{$\begin{array}{l}\text { Ombro- } \\
\text { type**** }\end{array}$} \\
\hline & & & & It & Ic & Iov3 & Iov4 & & & \\
\hline Parenti & 830 & 1394 & 11.9 & 196.9 & 17.7 & 1.3 & - & 1 & 1 & 1 \\
\hline Pinutello C.C. & 1005 & 1136 & 11.1 & 162.4 & 17.9 & 1.7 & - & 1 & 2 & 2 \\
\hline S. Giovanni in Fiore & 1050 & 1153 & 10.7 & 151.3 & 17.9 & 1.7 & - & 1 & 2 & 2 \\
\hline Cecita (ex Acquacalda) & 1180 & 1083 & 8.9 & 113.4 & 17.0 & 1.6 & - & 1 & 3 & 2 \\
\hline Stratalati C.C. & 1200 & 1324 & 9.7 & 118.6 & 18.0 & 1.2 & - & 1 & 3 & 1 \\
\hline Savuto C.C. & 1205 & 1355 & 9.7 & 117.5 & 18.0 & 1.3 & - & 1 & 3 & 1 \\
\hline Lorica & 1290 & 1229 & 9.1 & 98.4 & 18.1 & 2.0 & 2.5 & 2 & 4 & 1 \\
\hline Camigliatello Silano & 1291 & 1631 & 9.3 & 100.5 & 18.1 & 2.0 & 2.9 & 2 & 4 & 3 \\
\hline Quaresima C.C. & 1300 & 1577 & 9.0 & 96.2 & 18.1 & 2.0 & 3.3 & 2 & 4 & 3 \\
\hline Nocelle & 1322 & 1205 & 8.9 & 91.3 & 18.1 & 2.0 & 2.6 & 2 & 4 & 1 \\
\hline Longobucco & 770 & 1258 & 12.8 & 215.1 & 17.7 & 1.3 & - & 1 & 1 & 2 \\
\hline Bocchigliero & 870 & 1257 & 12.1 & 192.6 & 17.7 & 1.3 & - & 1 & 5 & 2 \\
\hline Fiorenza & 1126 & 1272 & 10.3 & 135.2 & 18.0 & 2.1 & - & 2 & 6 & 2 \\
\hline Casa Pasquale & 1246 & 1398 & 9.4 & 108.3 & 18.1 & 1.8 & 2.3 & 2 & 4 & 1 \\
\hline Casa Jolanda & 1250 & 1615 & 9.4 & 107.4 & 18.1 & 2.2 & - & 2 & 4 & 3 \\
\hline Barberano C.C. & 1280 & 1346 & 9.2 & 100.7 & 18.1 & 2.2 & - & 2 & 4 & 1 \\
\hline Trepidò & 1295 & 1305 & 9.0 & 97.3 & 18.1 & 1.8 & 2.3 & 2 & 4 & 1 \\
\hline Vivoli C.C. & 1300 & 1311 & 9.0 & 96.2 & 18.1 & 1.8 & 2.9 & 2 & 4 & 1 \\
\hline Sculca & 1358 & 1318 & 8.6 & 83.2 & 18.1 & 1.8 & 2.8 & 2 & 4 & 1 \\
\hline
\end{tabular}



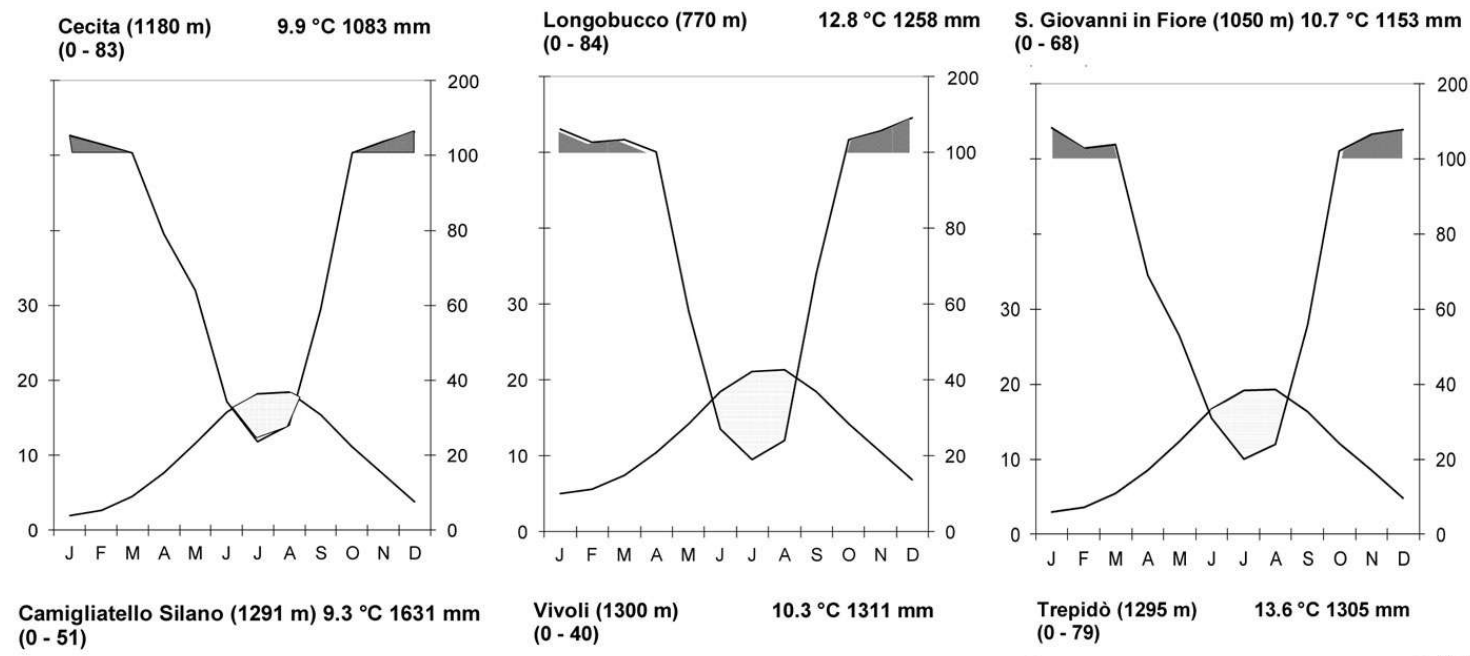

Camigliatello Silano $(1291 \mathrm{~m}) 9.3^{\circ} \mathrm{C} 1631 \mathrm{~mm}$ $(0-51)$
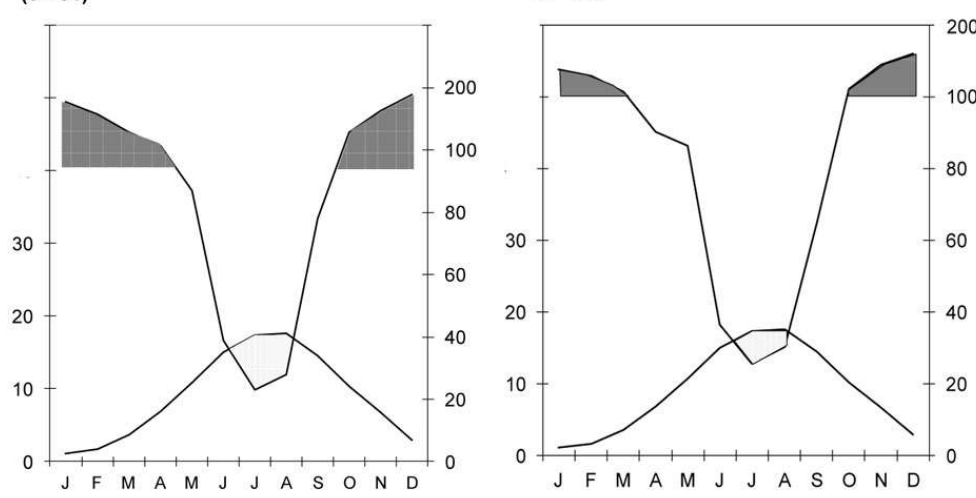

$(0-68)$

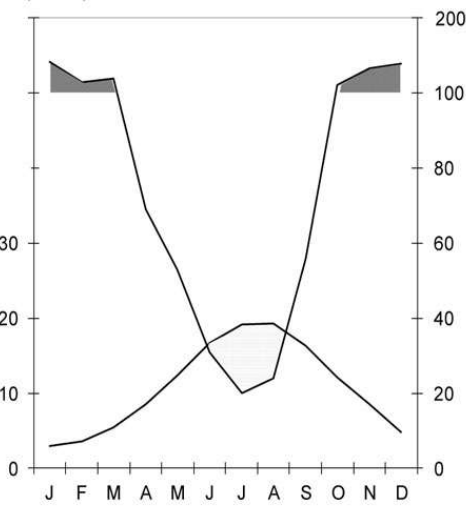

Trepidò $(1295 \mathrm{~m}) \quad 13.6^{\circ} \mathrm{C} 1305 \mathrm{~mm}$

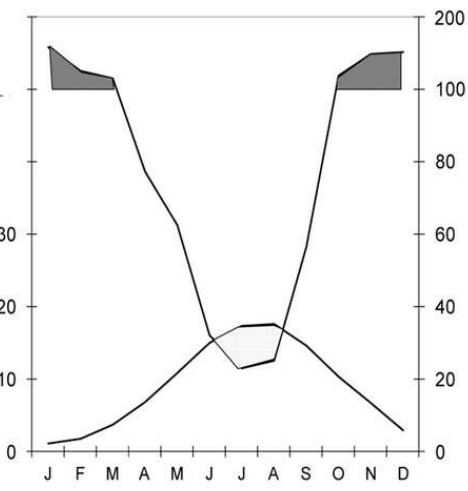

Fig. 6 - Climate diagrams of 6 weather stations: Cecita, Longobucco, San Giovanni in Fiore, Camigliatello Silano, Vivoli, and Trepidò.

deep with a common skeleton, a medium coarse texture, acidic, a moderate water reserve, and good drainage (ARSSA 2003).

In the southern zone, Calabrian pine grew on slight slopes on soils originated from

metamorphic rocks: Typic Dystrudept and Humic Dystrudept (TD_HD); and Humic Lithic Dystrudept, Humic Dystrudept, and Rock outcrop (HLD HD RO). In the TD_HD soils, the most common profiles were: (i) A-Bw-C, moderately deep, with frequent skeleton, high stoniness, medium texture, acid to sub-acid, moderate water reserve, and good drainage; (ii) Oi-A-Bw-BC, moderately deep, with common skeleton,

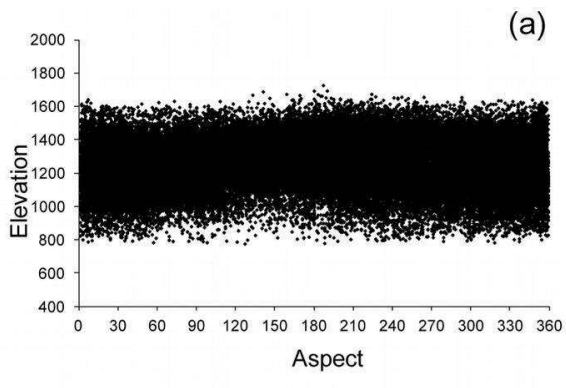

(d)

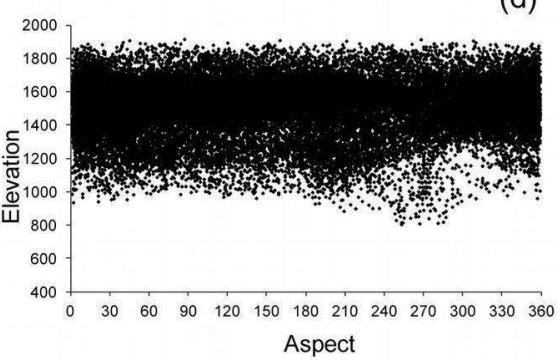

(b)
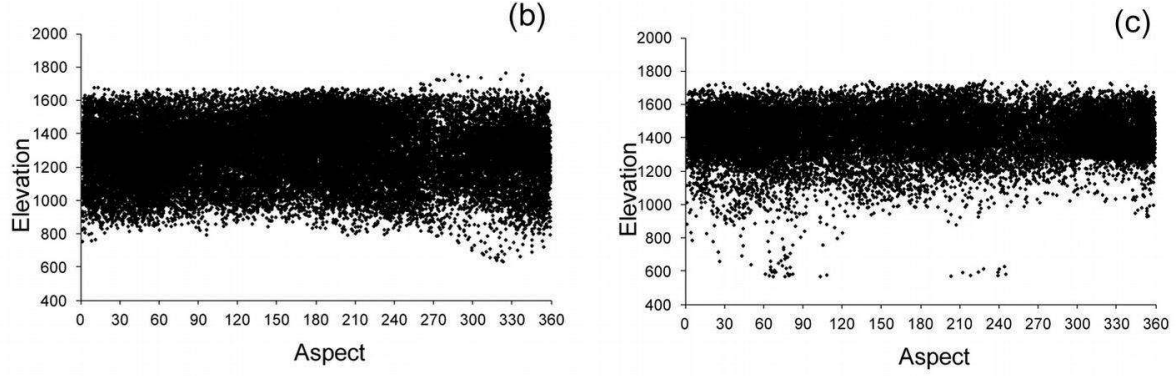

(e)

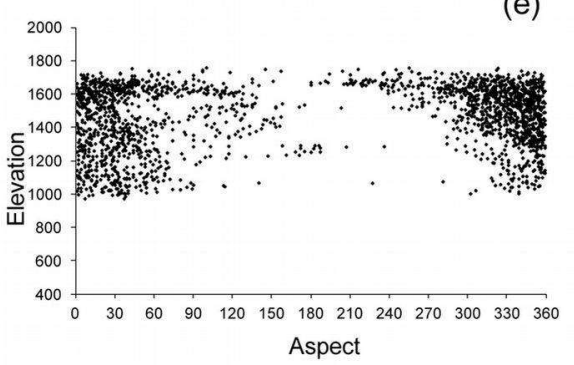

Fig. 7 - Scatter-plots depicting the relationships between elevation in $\mathrm{m}$ above sea level ( $\mathrm{m}$ a.s.l.) and aspect (degrees): (a) Calabrian pine forest, (b) Mixed Calabrian pine-beech forest, (c) Beech forest with sparse Calabrian pine, (d) Beech forest, and (e) Mixed fir-beech forest. 
Tab. 5 - Results of the binary logistic regression $(n=364)$ explaining pine-persistence during 1935-2006 (see Tab. 1 for independent variable description). (B): coefficient; (SE): standard error; (Wald): Wald's statistics; Exp (B): exponential of B coefficient.

\begin{tabular}{lccccc}
\hline $\begin{array}{l}\text { Independent } \\
\text { variable }\end{array}$ & B & SE & Wald & $\boldsymbol{p}$-value & $\begin{array}{c}\text { Exp (B) or } \\
\text { Odds ratio }\end{array}$ \\
\hline Constant & 7.568 & 1.233 & 37.699 & 0.000 & 1934.750 \\
Bioclimate (1) & -2.322 & 0.475 & 23.888 & 0.000 & 0.098 \\
Elevation & -0.469 & 0.085 & 30.438 & 0.000 & 0.625 \\
Soil (HD_HPD) & -0.977 & 0.449 & 4.745 & 0.029 & 0.376 \\
Soil (HD_TD) & -2.267 & 0.647 & 12.275 & 0.000 & 0.104 \\
Soil (TD_HD) & -1.543 & 0.360 & 18.328 & 0.000 & 0.214 \\
Soil (HPD_HD_TD) & -0.235 & 0.345 & 0.464 & 0.496 & 0.790 \\
Soil (HLD_HD_RO) & -1.658 & 0.361 & 21.073 & 0.000 & 0.190 \\
Hosmer-Lemeshow test & 0.595 & - & - & - & - \\
\hline
\end{tabular}

Tab. 6 - Results of the binary logistic regression $(n=308)$ explaining pine-expansion during 1935-2006 (see Tab. 1 for independent variable description). (B): coefficient; (SE): standard error; (Wald): Wald's statistics; Exp (B): exponential of B coefficient.

\begin{tabular}{lccccc}
\hline \multicolumn{1}{c}{ Independent variable } & B & SE & Wald & $\boldsymbol{p}$-value & $\begin{array}{r}\text { Exp (B) or } \\
\text { Odds ratio }\end{array}$ \\
\hline Constant & 7.110 & 1.104 & 41.464 & 0.000 & 1224.098 \\
Elevation & -0.644 & 0.089 & 52.812 & 0.000 & 0.525 \\
Soil (HD_HPD) & 2.529 & 0.661 & 14.627 & 0.000 & 12.535 \\
Soil (HD_TD) & 2.107 & 0.636 & 10.955 & 0.001 & 8.221 \\
Soil (TD_HD) & 2.293 & 0.471 & 23.662 & 0.000 & 9.906 \\
Soil (HPD_HD_TD) & 1.303 & 0.491 & 7.046 & 0.008 & 3.681 \\
Soil (HLD_HD_RO) & 1.388 & 0.468 & 8.785 & 0.003 & 4.006 \\
Hosmer-Lemeshow test & 0.908 & - & - & - & - \\
\hline
\end{tabular}

Tab. 7 - Results of the binary logistic regression $(n=256)$ explaining pine-transition during 1935-2006 (see Tab. 1 for independent variable description). (B): coefficient; (SE): standard error; (Wald): Wald's statistics; Exp (B): exponential of B coefficient.

\begin{tabular}{lccccc}
\hline Independent variable & B & SE & Wald & $\boldsymbol{p}$-value & $\begin{array}{c}\text { Exp (B) or } \\
\text { Odds ratio }\end{array}$ \\
\hline Constant & -4.096 & 1.054 & 15.101 & 0.000 & 0.017 \\
Elevation & 0.289 & 0.074 & 15.387 & 0.000 & 1.335 \\
Hosmer-Lemeshow test & 0.000 & - & - & - & - \\
\hline
\end{tabular}

medium texture, acidic, water reserve from moderate to high, and good drainage. The HLD HD RO had very thin soils with an A$\mathrm{R}$ profile, frequent skeleton, coarse texture, acidic, very low water reserve, and fast drainage (ARSSA 2003).

\section{Correlation between forest classes and ecological variables}

The relationships between each ecological variable (geographic zones, elevation classes, bioclimate, and soil types) and forest classes are shown in Fig. 4. Scatter-plots reported in Fig. 7 depict the relationships between elevation and aspect: above $1600 \mathrm{~m}$ a.s.l., Calabrian pine forests were located mainly on warm aspects, whereas below $800 \mathrm{~m}$ a.s.l., mixed Calabrian pine-beech forests and beech forests with sparse Calabrian pine were present mainly in cool aspects at all elevations. Mixed fir-beech forests were present only in cool aspects.

The logistic regression analysis shows that among the 5 independent variables describing the study area, bioclimate, elevation, and soil type were the variables best explaining the persistence of Calabrian pine. The Hosmer-Lemeshow test revealed that the model accounted for significant portion of variance for the pine persistence in 19352006 (Tab. 5). All explanatory variables were significant $(\mathrm{p}<0.05)$ except the soil type HPD HD TD, with an odds ratio $<1$, indicating that the probability of persistence of pine decreased from the oceanic Mediterranean bioclimate to higher elevations, in soil types HD_HPD, HD_TD, TD_HD, and HLD HD RO. Based on the Wald's values, the most important factor for the probability of pine-persistence was elevation, followed by bioclimate and soil type HLD_HD_RO.

For Calabrian pine expansion, the logistic regression indicates that the most important predictors were elevation and soil type. The Hosmer-Lemeshow test shows that the model fit was acceptable (Tab. 6). All ex- planatory variables were significant $(\mathrm{p}<0.05)$. An odds ratio $<1$ for elevation indicates that the greater the altitude the less probability of expansion of pine; and an odds ratio $>1$ for soil type indicates that the likelihood of expansion increased in the soils HD_HPD, HD TD, TD HD, HPD HD TD, and HLD HD RO. Based on Wald's statistics, the most important factor for the likelihood of expansion was elevation, followed by soil type TD HD.

For Calabrian pine transition, only elevation $(p<0.05)$ was included in the model with an odds ratio $>1$, i.e., the probability of transition increased with altitude. However, in this case the Hosmer-Lemeshow test indicates that the model did not fit the data adequately (Tab. 7).

\section{Discussion and conclusions}

Despite forest changes between 1935 and 2006, Calabrian pine covers today extensive areas in the Sila mountain range. Our results show that the most important ecological drivers of Calabrian pine distribution are elevation, soil type and bioclimate. The probability of pine-persistence during the period $1935-2006$ is significantly correlated with all of these explanatory variables. As shown in Fig. 8, pine-persistence prevails below 1400 $\mathrm{m}$ a.s.1., in a temperate oceanic bioclimate on thin and very eroded soils with low waterholding capacity (HPD HD RO), or on moderately deep soils with high water content and good drainage (HPD_HD TD). Above $1600 \mathrm{~m}$ a.s.1., depending on aspect and climatic restrictions Calabrian pine is rare (Fig. 7).

The likelihood of pine-expansion is significantly correlated with elevation and soil type. In the last 70 years, pine-expansion occurred especially below $1400 \mathrm{~m}$ a.s.l., on thin and very eroded soils with low water-holding capacity (HLD_HD_RO), and on moderately deep soils with good drainage, and waterholding capacity from moderate (TD_HD) to high (HPD_HD_TD - Fig. 8). Below $1400 \mathrm{~m}$ a.s.l., reforestation has been the main cause of Calabrian pine expansion (Iovino \& Menguzzato 2002a, 2002b).

Pine transition seems related to elevation, though our model prediction for transition did not adequately fit the data. Nonetheless, our results shows that transition prevails above $1200 \mathrm{~m}$ a.s.l. in moderately deep soils with high water content (HPD HD TD).

In the Sila mountain range there is historical evidence that intense soil erosion following forest destruction for agriculture and grazing started between the first and second millennium $\mathrm{BC}$, with the Bruzi occupation (Dimase et al. 1996). Thus, Calabrian pine spreading, which was initiated in that period, can be associated to human-induced soil degradation. The presence of pine stands in many beech dominated forests, and the pre- 
sence of mixed fir-beech forests is probably an example of the forest type characterizing the Sila mountain range before the destruction performed first by the Bruzi and then by the Romans. Beech forests with sparse Calabrian pine and pure pine forests can be considered as a simplified form of the mixed forest due to human impact: indeed, where human pressure was stronger (large clear cuts in beech forests and repeated fires) pine replaced beech, and then pine was favored by the silvicultural systems used to manage pine forests (such as clear felling).

Based on our results, 4 potential dynamics can be outlined for Calabrian pine forests in the Sila mountain range. These dynamics are driven by ecological (elevation, bioclimate, and soil) and anthropogenic factors.

Below 1200 m a.s.l., in an oceanic Mediterranean bioclimate:

(A) In thin and very eroded soils, with coarse texture, fast drainage, low cation-exchange capacity, and low water-holding capacity (HPD HD RO), pure Calabrian pine forests grow at the lower limit of their distribution. Under these conditions, Calabrian pine is expected to dominate also in the future following both management or disturbance factors such as fire (Fig. 9a).

(B) In moderately deep soils with a scarce to common skeleton, moderately coarse texture, acid $\mathrm{pH}$, high water content, and good drainage (HPD_HD_TD), pure Calabrian pine forests may be maintained by forest management methods such as clear felling or the small group selection method described by Ciancio et al. (2006). Absence of management will favor instead the evolution towards pure or mixed broadleaved forests dominated by oaks. However, disturbances like wildfire might affect this forest dynamic, favoring natural pine regeneration and thus perpetuating the pine forest (Fig. 9b).

Above 1200 m a.s.l., in a temperate oceanic bioclimate:

(C) In thin and very eroded soils, with coarse texture, fast drainage, low cation-exchange capacity, and low water-holding capacity (HLD_HD_RO), pure and natural Calabrian pine forests curently prevail (Fig. $10 \mathrm{a}$ ), and will probably be prevailing also in the future following either management or fire occurrence (Fig. 9c).

(D) In moderately deep soils with common skeleton and a superficial stoniness, medium texture, acid to sub-acid $\mathrm{pH}$, moderate water-holding capacity and good drainage (TD_HD), pure Calabrian pine forests can be maintained by appropriate forest management methods (Ciancio et al. 2006), or by disturbance factors such as fire. Absence of management will instead favor the evolution towards beech dominated forests or mixed fir-beech forests (Fig. 9d).

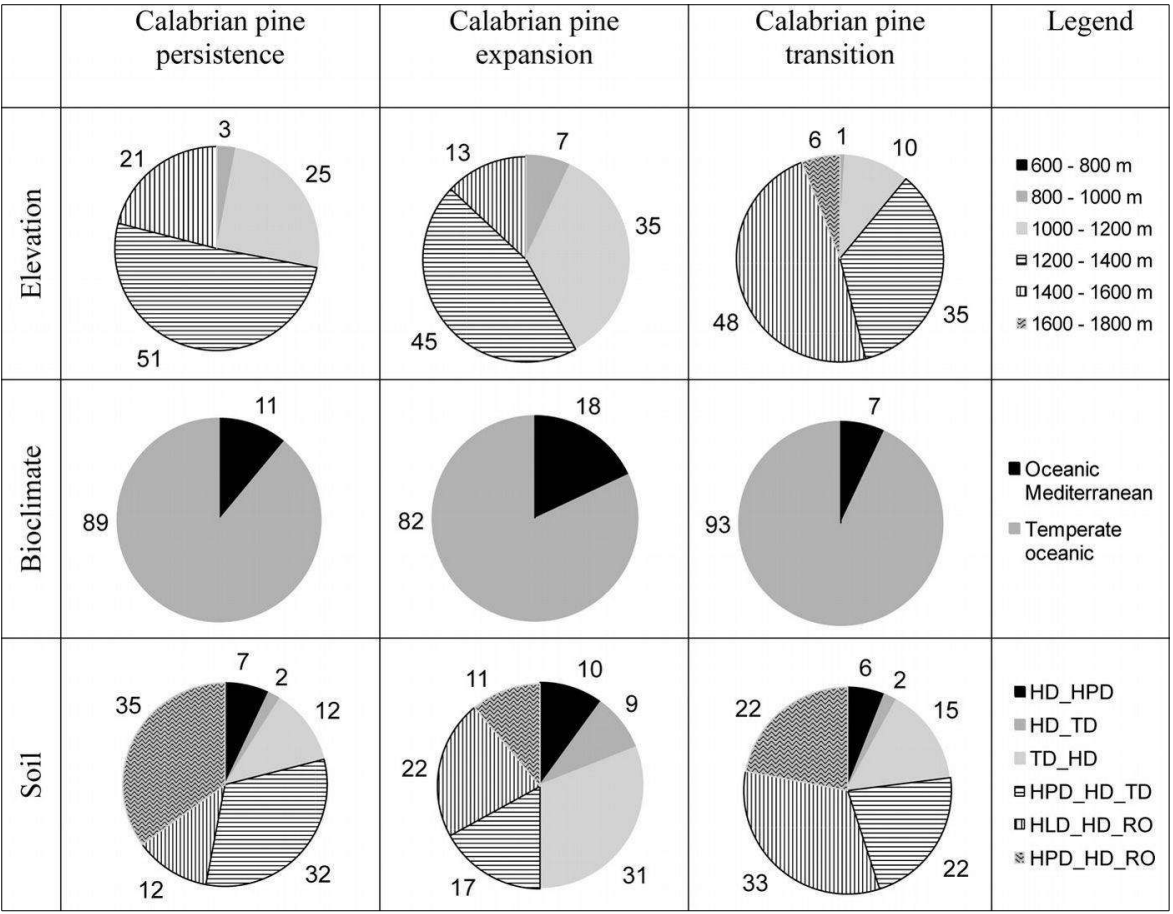

Fig. 8 - Calabrian pine changes during 1935-2006 (for each type of change, the area is a percentage of the total change) in relation to elevation, bioclimate, and soil (see Tab. 1 for soil type description).

Forest dynamics corresponding to (A) and (B) are expected for pine forests growing the Sila mountain range (Fig. 11). In these sectors, extensive reforestation with pines both in the northern and eastern sectors of was carried out in the past, while pine rege-

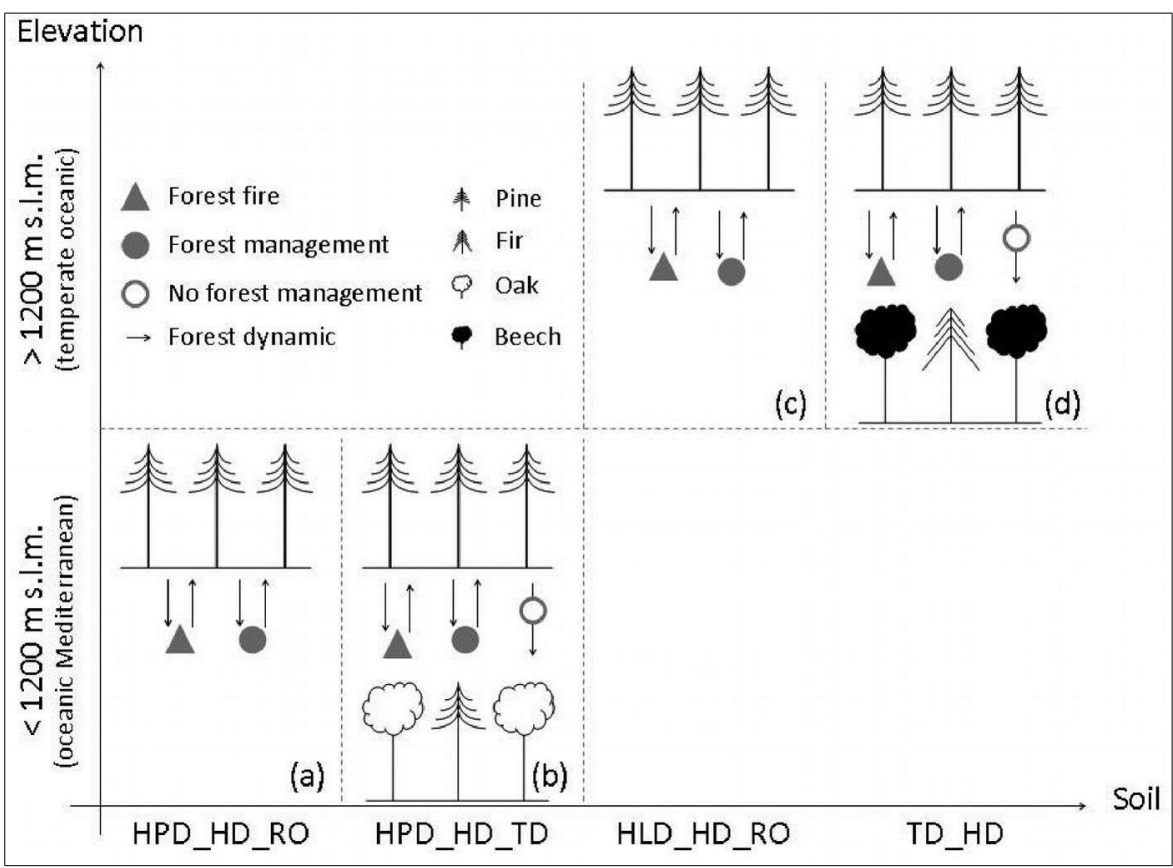

Fig. 9 - Potential Calabrian pine forest dynamics according to ecological (bioclimate, elevation, and soil), and anthropogenic (forest fire and forest management) drivers in the Sila mountain range: (a) pure Calabrian pine forest naturally originated: (b) Calabrian pine forest that might evolve into pure or mixed broadleaved forest dominated by oaks; (c) Calabrian pine plantations; and (d) Calabrian pine forest naturally originated that can be either maintained or transformed in beech dominated forest or in mixed fir-beech forest, according to forest management methods (see Tab. 1 for soil type description). 


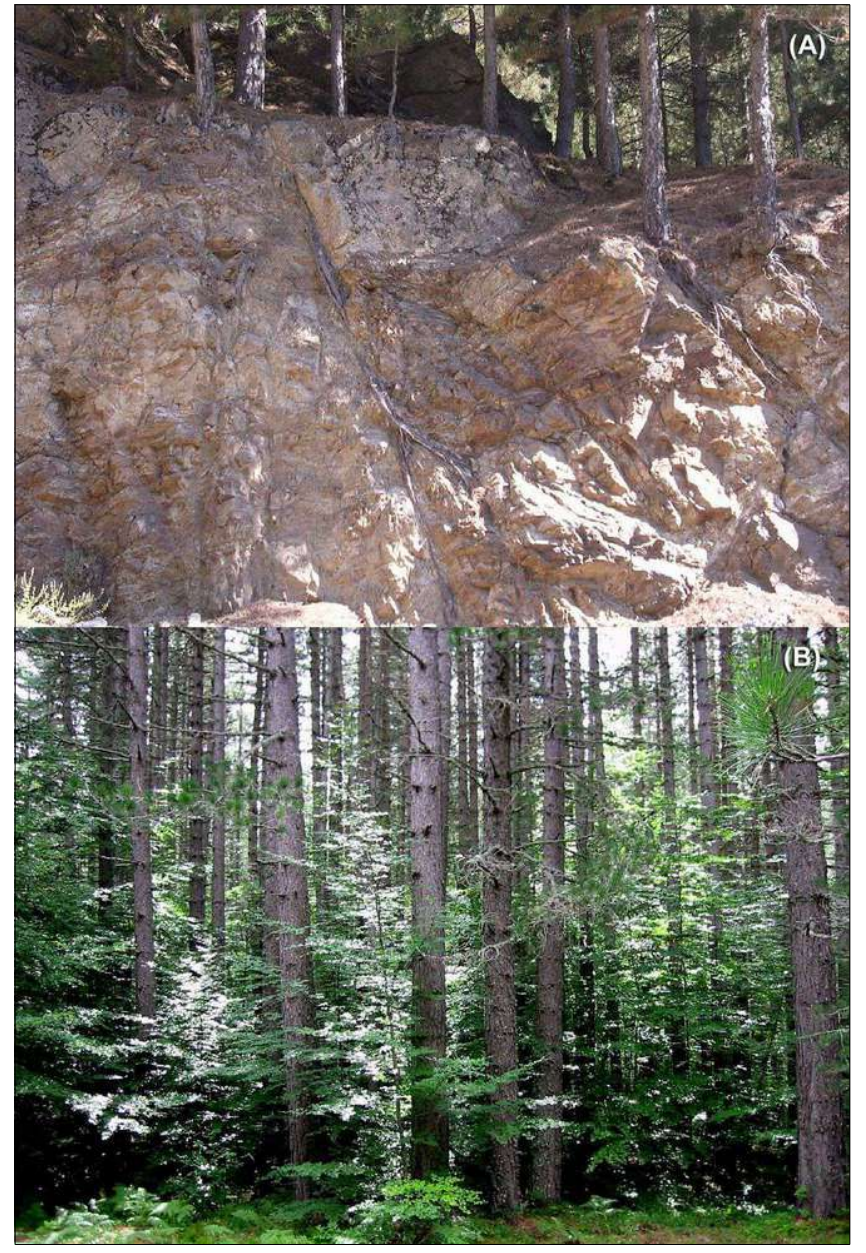

Fig. 10 - (A) Pure naturally originated Calabrian pine forest; (B) beech regeneration in a Calabrian pine forest (Photo: F. Iovino).

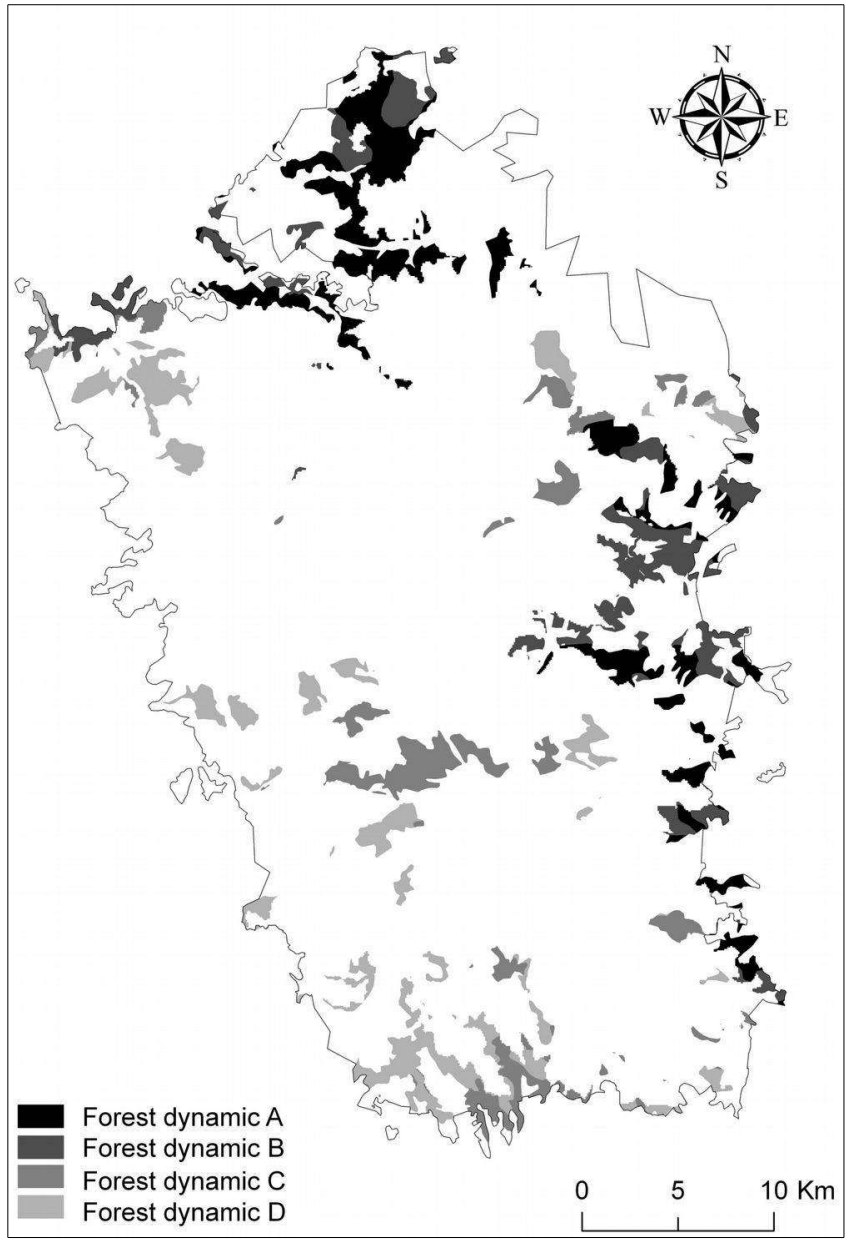

Fig. 11 - Potential Calabrian pine forest dynamics (including mixed Calabrian pine-beech forest) according to ecological (bioclimate, elevation and soil), and anthropogenic (forest fire and forest management) drivers in the Sila mountain range (see also Fig. 9). neration was favored by repeated fires. Forest dynamics corresponding to (C) and (D) prevail in the southern and western sectors of the Sila mountain range (Fig. 11), where pine forests are strongly influenced by management, or conversely by its absence. However, the tendency to evolve towards beech-dominated stands is very strong. Indeed, beech regeneration is quickly replacing pine where pine forests have not been managed in the last 40 to 50 years (Fig. 10b). In such cases, appropriate silvicultural systems must be used to favor pine regeneration for conservation purposes.

In conclusion, identifying potential Calabrian pine dynamics on the basis of ecological and anthropogenic factors can help forest managers define priorities for forest planning, such as landscape and habitat conservation, and management goals for pine plantations in a forest-priority habitat of community importance. Furthermore, our results may help understanding the possible response and adaptation potential of Calabrian pine to changes both in management and in envi- ronmental factors, such as expected climate change.

\section{Acknowledgments}

We thank four anonymous reviewers for their helpful suggestions and comments on an early version of the manuscript.

\section{References}

Arndt N, Vacik H, Koch V, Arpaci A, Gossow H (2013). Modelling human-caused forest fire ignition for assessing forest fire danger in Austria. iForest 6: 315-325. - doi: 10.3832/ifor0936-006 ARSSA (2003). I Suoli della Calabria. Carta dei suoli in scala 1:250,000 della regione Calabria [Soils of Calabria. Soil map of Calabria Region, scale 1:250,000]. Servizio Agropedologia, Monografia Divulgativa. Rubbettino Industrie Grafiche ed Editoriali Soveria Mannelli, Catanzaro, Italy. [in Italian]

Badia A, Serra P, Modugno S (2011). Identifying dynamics of fire ignition probabilities in two representative Mediterranean wildland-urban interface areas. Applied Geography 31: 930-940. doi: 10.1016/j.apgeog.2011.01.016
Barbéro M, Loisel R, Quézel P, Richardson DM, Romane F (2000). Pines of the Mediterranean Basin. In: "Ecology and Biogeography of Pinus" (Richardson DM ed). Cambridge University Press, UK, pp. 153-167. [online] URL: http://bo oks.google.com/books?id=YawYOzQmcHEC

Barreca L, Coletta V, Gentile F, Marziliano PA, Scuderi A (2009). Struttura delle pinete di laricio dell'Etna: il caso della pineta Ragabo [Stand structure of Etna Calabrian pine forests: the Ragabo pine forest case]. In: Proceedings of the "Terzo Congresso Nazionale di Selvicoltura" (Ciancio O ed). Taormina (ME, Italy), 16-19 October 2008. Accademia Italiana di Scienze Forestali, Firenze, Italy, pp. 95-100. [in Italian]

Blasi C, Chirici G, Corona P, Marchetti M, Maselli F, Puletti N (2007). Spatialization of climatic data at the Italian national level by local regressive models. Forest@ 4 (2): 213-219. [in Italian with English summary] - doi: 10.3832/ efor0453-0040213

Blondel J (2006). The "design" of Mediterranean landscapes: a millennial story of humans and ecological systems during the historic period. Human Ecology 34: 713-729. - doi: 10.1007/s10745- 
006-9030-4

Blondel J, Aronson J (1995). Biodiversity and ecosystem function in the Mediterranean basin: human and non-human determinants. In: "Mediterranean-Type Ecosystems. The Function of Biodiversity" (Davis GW, Richardson DM eds.). Springer-Verlag, Berlin, Germany, pp. 43-119. doi: 10.1007/978-3-642-78881-9_2

Bonora N, Munafò M, Chirici G, Marchetti M (2011). Analisi conclusive relative alla cartografia Corine Land Cover 2000 [Concluding analysis relating to cartography Corine Land Cover 2000]. ISPRA, Rapporti 130/2010, Rome, Italy, pp. 128. [in Italian]

Botequim B, Garcia-Gonzalo J, Marques S, Ricardo A, Borges JG, Tomé M, Oliveira MM (2013). Developing wildfire risk probability models for Eucalyptus globulus stands in Portugal. iForest 6: 217-227. - doi: 10.3832/ifor0821-006

Chirici G, Corona P, Köehl M (2006). Earth observation techniques and GIS as tools for assessing land use/cover changes in a landscape context. In: "The conservation of cultural landscapes" (Agnoletti $\mathrm{M}$ ed). CAB International, Wallingford, UK, pp. 57-70.

Ciancio O (1971). Sul clima e sulla distribuzione altimetrica della vegetazione forestale in Calabria [Climate and altitude distribution of forest vegetation in Calabria]. Annali Istituto Sperimentale per la Selvicoltura 2: 323-372. [in Italian]

Ciancio O, Iovino F, Menguzzato A, Nicolaci A, Nocentini S (2006). Structure and growth of a small group selection forest of Calabrian pine in Southern Italy: a hypothesis for continuous cover forestry based on traditional silviculture. Forest Ecology and Management 224: 229-234. - doi: 10.1016/j.foreco.2005.12.057

Debazac EF (1965). Les pineraies de Calabre et de Sicile [Pine forests of Calabria and Sicily]. Revue Forestière Française 17 (10): 662-673. [in French] - doi: 10.4267/2042/24690

DeSoto L, Olano JM, Rozas V, De la Cruz M (2010). Release of Juniperus thurifera woodlands from herbivore-mediated arrested succession in Spain. Applied Vegetation Science 13: 15-25. doi: 10.1111/j.1654-109X.2009.01045.x

Dimase AC, Iovino F (1996). I suoli dei bacini idrografici del Trionto, Nicà e torrenti limitrofi (Calabria) [The soils of the catchment areas of the Trionto, Nicà and neighboring streams $(\mathrm{Cal}-$ abria)]. Pubblicazioni dell'Accademia Italiana di Scienze Forestali, Nuova Stamperia Firenze, Firenze, Italy, pp. 1-112. [in Italian]

Dimase AC, Iovino F, Bonazzi A (1996). Effetti dell'impatto antropico sull'erosione dei suoli dell'altopiano della Sila (Calabria) [Effects of human impact on erosion of soils of the plateau of the Sila (Calabria)]. Annali dell'Accademia Italiana di Scienze Forestali 45: 307-329. [in Italian]

Dramis F, Gentili B, Pambianchi G (1990). Geomorphological scheme of the River Trionto basin. In: "Excursion guide-book - IGUCoMTAG Symposium on Geomorphology of Active Tectonic Areas" (Sorriso-Valvo M ed). CNR-IRPI, Rende, Cosenza, Italy, 31 May - 8 June 1990. Geodata
39: 71-75.

EC (2007). Interpretation manual of European union habitats EUR 27. Web site, European Commission, Brussels, Belgium. [online] URL: $\mathrm{http} / /$ ec.europa.eu/environment/nature/legislation/habitatsdirective/docs/2007_07_im.pdf Eeckhaut MVD, Vanwalleghem T, Poesen J, Govers G, Verstraeten G, Vandekerckhove L (2006). Prediction of landslide susceptibility using rare events logistic regression: a case-study in the Flemish Ardennes (Belgium). Geomorphology 76: 392-410. - doi: 10.1016/j.geomorph.2005.12. 003

Fady-Welterlen B (2005). Is there really more biodiversity in Mediterranean forest ecosystems? Taxon 54: 905-910. - doi: 10.2307/25065 477

Getahun K, Van Rompaey A, Van Turnhout P, Poesen J (2013). Factors controlling patterns of deforestation in moist evergreen Afromontane forests of Southwest Ethiopia. Forest Ecology and Management 304: 171-181. - doi: 10.1016/j.foreco.2013.05.001

Hair JF, Black B, Babin B, Anderson RE, Tatham RL (2006). Multivariate data analysis $\left(6^{\text {th }}\right.$ edn). Prentice Hall, Upper Saddle River, New Jersey, pp. 899.

Hoersch B, Braunb G, Schmidtb U (2002). Relation between landform and vegetation in alpine regions of Wallis, Switzerland. A multiscale remote sensing and GIS approach. Computers, Environment and Urban Systems 26: 113-139. doi: 10.1016/S0198-9715(01)00039-4

Iovino F, Menguzzato G (1996). A return to complex formations through forest management. In: "The forest and man" (Ciancio O ed). Accademia Italiana di Scienze Forestali, Tipografia Coppini, Florence, Italy, pp. 211-221.

Iovino F, Menguzzato G (2002a). Rimboschimenti in Calabria: storia e significato [Reforestation in Calabria: the history and meaning]. In: Proceedings of the " $12^{\circ}$ Seminario IAED on Rimboschimenti e piantagioni nelle trasformazioni del paesaggio" (Corona P, Marchetti M eds). Edizioni Papageno, Palermo, Italy, pp. 109-122. [in Italian]

Iovino F, Menguzzato G (2002b). Disboscamento e ripristino del manto boschivo nell'Appennino calabrese [Deforestation and retrieval of forest cover in the Calabrian Apennines]. In: "Disboscamento montano e politiche territoriali. Alpi e Appennini dal Settecento al Duemila" (Lazzarini A, Angeli Storia F), pp. 494-509. [in Italian] [PLEASE INSERT THE PUBLICATION PLACE]

Kleinbaum DG, Klein M (2002). Logistic regression. A self-learning text $\left(2^{\text {nd }}\right.$ edn). SpringerVerlag, New York, USA, pp. 516.

Li J, Dong S, Yang Z, Peng M, Liu S, Li X (2012). Effects of cascade hydropower dams on the structure and distribution of riparian and upland vegetation along the middle-lower Lancang-Mekong River. Forest Ecology and Management 284: 251-259. - doi: 10.1016/j.foreco.2 012.07 .050

LIFE (2005). Pin laricio - for a conservatory management of the laricio pine habitats. Project LIFE00 NAT/F/007273, European Commission, Web site. [online] URL: http://www.life pinlaricio.org

Linkie M, Smith RJ, Williams NL (2004). Mapping and predicting deforestation patterns in the lowlands of Sumatra. Biodiversity Conservation 13: 1809-1818. - doi: 10.1023/B:BIOC.000003 5867.90891.ea

Linares JC, Camarero JJ, Carreira JA (2009). Interacting effects of changes in climate and forest cover on mortality and growth of the southernmost European fir forests. Global Ecology and Biogeography 18: 485-497. - doi: 10.1111/ j.1466-8238.2009.00465.x

Lulli L, Vecchio G (1996). I suoli del bacino del Lago Cecita nella Sila Grande e la loro sensibilità [The soils of the basin of Lake Cecita in the Sila Grande and their sensitivity]. Agricoltura Ricerca 164/165/166: 113-122. [in Italian]

Lulli L, Vecchio G (2000). I suoli della Tavoletta "Lago Cecita" nella Sila Grande in Calabria [The soils of "Lake Cecita" in the Sila Grande in Calabria]. Monografia Istituto Sperimentale per lo Studio e la Difesa del Suolo, Progetto PANDA, Sottoprog. 2, serie 1, Catanzaro, Italy, pp. 78. [in Italian]

Matano F, Di Nocera S (1999). Weathering patterns in the Sila Massif (Northern Calabria, Italy). Il Quaternario, Italian Journal of Quaternary Sciences 12: 141-148.

Mertens B, Lambin EF (2000). A spatial model of land cover change trajectories in a frontier region in southern Cameroon. Annals of the Association of American Geographers 90: 467-494. - doi: 10.1111/0004-5608.00205

Médail F, Quézel P (1999). Hot-spots analysis for conservation of plant biodiversity in the Mediterranean Basin. Annals of the Missouri Botanical Garden 84: 112-127. - doi: 10.2307/2399957

MLP (1950). Annali idrologici - Parte Prima Sezione B, Manto nevoso [Annals hydrology Part One - Section B, Snow cover]. Ministero dei Lavori Pubblici, Servizio Idrografico. Stazione Autonoma di Catanzaro. Istituto Poligrafico dello Stato, Roma, Italy. [in Italian] [online] URL: http://www.cfd.calabria.it

Milizia Nazionale Forestale (1932). Carta Forestale, Fogli Rossano, Cosenza, san Giovanni in Fiore. Scala 1:100.000 [Forest map, sheets Rossano, Cosenza, san Giovanni in Fiore. Scale 1:100.000]. Istituto Geografico Militare, Firenze, Italy. [in Italian]

Molin P, Pazzaglia FJ, Dramis F (2004). Geomorphic expression of active tectonics in a rapidlydeforming forearc, Sila Massif, Calabria, Southern Italy. American Journal of Science 304: 559-589. - doi: 10.2475/ajs.304.7.559

Mon MS, Mizoue N, Htun NZ, Kajisa T, Yoshida S (2012). Factors affecting deforestation and forest degradation in selectively logged production forest: a case study in Myanmar. Forest Ecology and Management 267: 190-198. - doi: 10.1016/j. foreco.2011.11.036

Monzón-Alvarado C, Cortina-Villar S, Schmook B, Flamenco-Sandoval A, Christman Z, Arriola L 
(2012). Land-use decision-making after largescale forest fires: analyzing fires as a driver of deforestation in Laguna del Tigre National Park, Guatemala. Applied Geography 35: 43-52. - doi: 10.1016/j.apgeog.2012.04.008

Myers N, Mittermeier RA, Mittermeier CG, da Fonseca GAB, Kent J (2000). Biodiversity hotspots for conservation priorities. Nature 403: 853-858. - doi: 10.1038/35002501

Newman ME, McLaren KP, Wilson BS (2014). Long-term socio-economic and spatial pattern drivers of land cover change in a Caribbean tropical moist forest, the Cockpit Country, Jamaica. Agriculture, Ecosystems and Environment 186: 185-200. - doi: 10.1016/j.agee.2014.01.030

Pelorosso R, Leone A, Boccia L (2009). Land cover and land use change in the Italian central Apennines: a comparison of assessment methods. Applied Geography 29: 35-48. - doi: 10.1016/j.ap geog.2008.07.003

Petit CC, Lambin EF (2001). Impact of data integration technique on historical land-use/landcover change: comparing historical maps with remote sensing data in the Belgian Ardennes. Landscape Ecology 17: 117-132. - doi: 10.1023/A:10 16599627798

Poli Marchese E (1982). Zonation altitudinale de la végétation de l'Etna comparée avec celle d'autres hauts volcans [Altitudinal vegetation zonation of Etna compared with other high volcanoes]. Workshop NATO, Saint Maximin (Mar- seille, France) 16-20 nov 1981. Ecologie Mediterranéenne 8: 339-354. [in French]

Poljanec A, Ficko A, Boncina A (2010). Spatiotemporal dynamic of European beech (Fagus sylvatica L.) in Slovenia, 1970-2005. Forest Ecology and Management 259: 2183-2190. doi: 10.1016/j.foreco.2009.09.022

Quézel P, Médail F (2003). Ecologie et biogéographie des forêts du bassin Méditerranéen [Ecology and biogeography of Mediterranean basin forests]. Elsevier, Paris, pp. 573. [in French]

Rivas Martinez S (1995). Classificacion bioclimatica de la Tierra [Bioclimatic classification of Earth]. Folia Botanica Madritensis 16: 1-25. [in Spanish]

Scarciglia F, Le Pera E, Critelli S (2005). Weathering and pedogenesis in the Sila Grande Massif (Calabria, South Italy): from field scale to micromorphology. Catena 61: 1-29. - doi: 10.1016/j.ca tena.2005.02.001

Serneels S, Lambin EF (2001). Proximate causes of land-use change in Narok District, Kenya: a spatial statistical model. Agriculture, Ecosystems and Environment 85: 65-81. - doi: 10.101 6/S0167-8809(01)00188-8

Soil Survey Staff (1999). Soil taxonomy: a basic system of soil classification for making and interpreting soil surveys $\left(2^{\text {nd }} e d n\right)$. USDA-NRCS, Agricoltural Handbook 436, US Gov. Print Office, Washington, DC, USA, pp. 869
Sorriso-Valvo M (1993). The geomorphology of Calabria. A sketch. Geografia Fisica e Dinami-ca Quaternaria 16: 75-90.

Schweizer PE, Matlack GR (2014). Factors driving land use change and forest distribution on the coastal plain of Mississippi, USA. Landscape and Urban Planning 121: 55-64. - doi: 10.1016/j.landurbplan.2013.09.003

Tappeiner U, Tasser E, Tappeiner G (1998). Modelling vegetation patterns using natural and anthropogenic influence factors: preliminary experience with a GIS based model applied to an Alpine area. Ecological Modelling 113: 225-237. - doi: 10.1016/S0304-3800(98)00145-8

Thirgood JV (1981). Man and the Mediterranean forest. A history of resource depletion. Academic Press, Toronto, Canada, pp. 186. [online] URL: http://tocs.ulb.tu-darmstadt.de/60855533.pdf

Tongiorgi E (1938). Ricerche sulla vegetazione dell'Etruria marittima. VIII. La vegetazione del Monte Amiata durante l'ultime glaciazione [Researches on the vegetation of the Etruria maritime. VIII. The vegetation of Mount Amiata during the last glaciation]. Nuovo Giornale Botanico Italiano 45: 388-390. [in Italian] - doi: 10.108 $0 / 11263503809438759$

Zaghi D (2008). Management of Natura 2000 habitats. $9530 *(\mathrm{Sub})$-Mediterranean pine forests with endemic black pines. European Commission, Brussels, Belgium, pp. 23. 